\title{
POLA KOMUNIKASI TRANSENDENTAL DI MASA PANDEMI COVID-19 SEBAGAI USAHA MENJAGA KESEHATAN DIRI
}

\author{
Yuliana Maknolia $^{1)}$, Dini Rahmawati ${ }^{2)}$ \\ ${ }^{1) 2}$ Universitas Adhirajasa Reswara Sanjaya Bandung \\ Email : yulianamaknolia1105@gmail.com
}

\begin{abstract}
ABSTRAK
Kajian ini dilatarbelakangi oleh situasi pandemi COVID-19. COVID-19 merupakan penyakit yang disebabkan oleh virus dan saat ini tengah melanda Indonesia. Virus ini menular dengan cepat melalui udara, itu sebabnya penting bagi masyarakat untuk menaati protokol kesehatan 3M. Masyarakat lebih baik beraktivitas di dalam rumah dan memperbanyak kegiatan positif yang dapat menjaga kesehatan tubuh seperti makan makanan sehat dan bergizi, menjaga kebersihan dan menjalin komunikasi transendental (komunikasi manusia dengan Tuhan) yang baik. Penelitian ini dilakukan di beberapa RT (Rukun Tetangga) di RW (Rukun Warga) 06 di Desa Cicukang, Bandung. Penelitian ini menggunakan metode kualitatif. Peneliti melakukan wawancara dengan beberapa informan melalui online, mengobservasi kegiatan mereka yang berkaitan dengan komunikasi transendental, dan mengkaji literatur-literatur. Hasil penelitian menunjukkan bahwa seseorang yang taat dalam beribadah memiliki resiko lebih kecil mengalami stres. Selain itu, dengan menjadikan diri, hati dan pikiran fokus dalam beribadah dan berkomunikasi dengan Sang Pencipta melalui berdoa dan berdzikir maka diri akan teralihkan dari kecemasan terhadap virus corona. Hal ini menimbulkan pengaruh positif pada diri sehingga berkurangnya kemungkinan terpapar virus.
\end{abstract}

Kata Kunci: COVID-19; Komunikasi Transendental; Kesehatan Diri; Stres

\section{PENDAHULUAN}

Bermula dari memahami konsep komunikasi sebagai proses satu arah yang secara sederhana menggambarkan orientasi pada sumber. Hal ini seperti diungkapkan oleh Burgoon (dalam Wiryanto, 2005) yang berorientasi pada sumber (source-oriented definition). Komunikasi merupakan proses penyampaian pesan yang dilakukan oleh komunikator kepada komunikan dengan menggunakan media sebagai sarana untuk menyampaikan pesan. Komunikasi juga diartikan sebagai ilmu yang multidisipliner dikembangkan melalui dukungan dari ilmu lainnya. Banyak realitas-realitas komunikasi yang harus dipotret dengan cara kerjasama antara ilmu komunikasi dengan ilmu-ilmu lainnya seperti ilmu sosiologi, psikologi dan ilmu agama. Seperti halnya komunikasi yang dilakukan oleh manusia dengan Tuhannya dapat dianggap sebagai fenomena komunikasi atau yang dikenal dengan pola komunikasi transendental.

Ada beberapa perspektif mengenai maksud dari komunikasi transendental. Dalam pandangan Islam komunikasi transendental diartikan sebagai komunikasi antara hamba dengan sesuatu yang berpusat pada qolbu. Adapun menurut Profesor Syam (2015) bahwa komunikasi transendental adalah komunikasi yang berlangsung di dalam diri dengan sesuatu di luar diri yang disadari keberadaannya oleh individu tersebut. Secara luas komunikasi transendental dapat diartikan sebagai komunikasi yang melibatkan manusia dengan
Tuhannya. Manusia harus membangun hubungan horizontal yakni dengan manusia lainnya dan vertikal dengan Tuhannya. Hubungan ini akan membawa seorang individu menjadi manusia paripurna. Hubungan ini dapat diartikan pula dengan melihat tiga perspektif transendental yaitu penerimaan, respon dan reaksi. Istilah ini yang merujuk pada sisi kemanusiaan yaitu bahwa manusia memberikan reaksi dan respon atas komunikasi dirinya yang menerima pesan dari Tuhan. Sebagai seorang muslim pola komunikasi transendental yang dilakukan salah satunya adalah melakukan ibadah shalat dan berdoa sebagai salah satu cara untuk berkomunikasi dengan Allah SWT. Ayat-ayat yang ada di dalam Al-Quran merupakan pesan yang ditunjukkan Allah SWT untuk hambaNya sebagai petunjuk dan tuntunan hidup.

Stres merupakan masalah yang tidak asing bagi kehidupan manusia. Kupriyanov dan Zhdanov (2014) menyatakan bahwa stres yang terjadi saat ini adalah sebuah atribut dalam kehidupan yang modern. Hal ini karena stres sudah menjadi bagian hidup yang tak terelakkan dari setiap manusia. Baik di lingkungan sekolah, kerja, masyarkat bahkan lingkungan keluarga sekalipun. Permasalahan yang terjadi adalah apabila jumlah stres yang begitu banyak dialami seseorang dapat berakibat buruk sehingga membahayakan kondisi fisik dan mental. Lin dan Huang (2014) menyatakan bahwa stres yang jumlahnya begitu banyak dapat membahayakan kepada setiap individu. 
Secara umum stres adalah perasaan tertekan, cemas dan tegang. Menurut Chapplin (2012) stres adalah keadaan internal yang dapat diakibatkan oleh tuntutan fisik dari tubuh atau kondisi lingkungan dan sosial yang dinilai potensial membahayakan, tidak terkendali atau melebihi kemampuan individu untuk mengatasinya. Stres juga adalah suatu keadaan tertekan, baik secara fisik maupun psikologis.

Dalam masa pandemi ini sangat penting untuk menjaga kesehatan diri dan mengendalikan stres dalam tubuh. Hal ini berguna untuk menjaga imunitas tubuh agar tetap dalam keadaan baik sehingga tubuh dapat melawan virus yang berusaha masuk. Hal penting yang juga mempengaruhi stres dalam tubuh kita adalah bagaimana pola komunikasi transendental atau yang kita tahu sebagai komunikasi yang dilakukan antara manusia dan Tuhan dapat berperan dalam pengendalian stres. Misalnya semakin kita sering beribadah dan berdoa seperti melaksanakan shalat dan berdzikir maka secara otomatis tubuh kita akan menstimulus energi positif yang sangat bermanfaat untuk mengendalikan stres.

Covid-19 merupakan jenis virus yang baru sehingga banyak pihak yang belum mengetahui dan mengerti cara penanggulangan virus tersebut. Seiring mewabahnya virus Corona atau Covid-19 ke ratusan negara, pemerintah Republik Indonesia menerbitkan protokol kesehatan. Protokol tersebut dilaksanakan di seluruh Indonesia dipandu secara terpusat oleh Kementerian Kesehatan RI (2020). Hingga pada penjelasan dan tata cara penanganan Covid-19 tidak ada persoalan, namun ternyata virus terus menular secara meluas dan seakan tidak bisa tertangani sehingga membuat Ketua DPR RI berkali-kali mengingatkan pemerintah agar segera membentuk tim nasional penanganan wabah virus korona yang bersifat terpusat (CNN Indonesia, 2020). Selain itu, karena kurangnya informasi membuat masyarakat di berbagai daerah mengeluh, bingung dan semakin khawatir akibat tidak mendapatkan pelayanan secara aman dan meyakinkan ketika ada indikasi terpapar virus Covid-19.

Semenjak adanya penyebaran Covid-19, tingkat kecemasan dan ketakutan masyarakat meningkat. Hal ini yang membuat seseorang mudah terpapar Covid-19. Dengan kecemasan dan katakutan yang berlebihan membuat tubuh memberikan respon yang negatif. Inilah salah satu penyebab mudahnya seorang individu menjadi stres dan kondisi kesehatannya menurun. Padahal apabila respon yang diberikan tetap tenang namun berhati-hati, tentu tidak akan ada perubahan negatif dalam tubuh. Terutama jika seseorang rajin dalam beribadah, pola pikirnya akan lebih tenang dan terjaga, sehingga imunitasnya akan tetap terjaga dengan baik dan tubuh pun siap melawan berbagai virus dan bakteri yang masuk tanpa adanya keluhan berat yang dapat dirasakan tubuh. Dengan menjadikan diri, hati dan pikiran fokus dalam beribadah dan berkomunikasi dengan Sang Pencipta melalui berdoa dan berdzikir maka diri akan teralihkan dari kecemasan terhadap virus corona, dan hal ini akan berakibat positif dengan berkurangnya kemungkinan terpapar virus.

\section{METODE}

Penelitian ini menggunakan pendekatan etnografi komunikasi. Menurut Koentjaraningrat (2014:15) etnografi komunikasi adalah mempelajari bahasa komunikasi dan perilaku sosial dalam masyarakat (disebut masyarakat tutur). Hal ini selaras dengan tujuan penelitian yang bermaksud untuk mengetahui pola komunikasi yang telah menjadi budaya dan kebiasaan dalam lingkungan masyarakat. Peneliti menggunakan pendekatan etnografi komunikasi untuk memahami cara orang-orang dalam satu lingkungan berinteraksi dalam kehidupan sehari hari melalui pola komunikasi transendental yaitu komunikasi antara manusia dengan Allah SWT melalui ibadah, berdoa dan berzikir yang telah menjadi kebiasaan dan budaya dalam lingkungan masyarakat beragama. Penelitian tersebut tidak bermaksud mengkuantifikasikan hasil penelitian atau menghitung data (Afrizal, 2017). Maka dari itu, penelitian ini menggunakan metode kualitatif. Menurut Moleong (2005:6) penelitian kualitatif adalah jenis penelitian yang bertujuan untuk memahami fenomena yang dialami oleh objek penelitian secara keseluruhan melalui deskripsi bahasa dan teks, seperti bahasa perilaku, persepsi, motivasi, tindakan dan lain-lain, dalam konteks khusus alamiah dan melalui penggunaan berbagai metode alamiah.

Dalam penelitian ini, peneliti terjun langsung ke lapangan untuk melakukan eksplorasi terhadap objek penelitian. Dengan memfokuskan pada tujuan mengenai pola komunikasi transendental yang mempengaruhi kesehatan masyarakat selama pandemi covid-19, serta faktor yang mempengaruhi objek penelitian, dimana objek dari penelitian ini adalah nilai-nilai, budaya dan norma agama yang telah menjadi kebiasaan dalam lingkungan masyarakat. Dalam penelitian kualitatif, semakin mendalam, teliti dalam menggali data yang diperoleh maka semakin baik kualitas penelitian. Oleh karena itu, dapat dilihat dari jumlah responden atau objek penelitian, metode penelitian kualitatif memiliki objek yang lebih sedikit dibandingkan penelitian kuantitatif, karena lebih mengutamakan kedalaman data daripada kuantitas data.

Paradigma yang digunakan dalam riset ini merupakan paradigma konstruktivis. Paradigma konstruktivis menempatkan suatu pengamatan serta objektivitas dalam menciptakan kenyataan ataupun konsep ilmu pengetahuan. Konstuktivis 
memandang ilmu sosial sebagai analisis sistematis terhadap tindakan sosial bermakna lewat pengamatan kepada pelaku sosial untuk menghasilkan ataupun mengelola dunia sosial (Nadya \& Hidayat, 2016).

Dalam penelitian etnografi komunikasi, peneliti bermaksud untuk menggambarkan bagaimana masyarakat yang dijadikan informan menciptakan pola komunikasi transendental (komunikasi manusia dengan Allah SWT) sebagai suatu kebiasaan dan budaya yang melekat seperti kebiasaan beribadah dan berdoa.

\section{HASIL DAN PEMBAHASAN}

Pada bab ini peneliti akan memaparkan hasil penelitian yang telah dilakukan oleh peneliti mengenai pola komunikasi transendental dalam upaya pengendalian stres dan kesehatan diri selama pandemi. Peneliti mencari tahu bagaimana masyarakat menerapkan pola komunikasi transendental menjadi suatu kebiasaan positif yang bermanfaat sebagai kesehatan jasmani dan rohani seperti beribadah, bedoa dan berzikir. Dalam penelitian ini peneliti juga akan membahas mengenai besarnya peran komunikasi yang dilakukan dengan Allah SWT yang dapat menjadikan kekuatan dan ketenangan dalam diri yang akan sangat berpengaruh terhadap kesehatan dalam melawan pandemi virus corona saat ini.

Penelitian ini menggunakan pendekatan kualitatif dengan jenis penelitian etnografi komunikasi. Dalam penggunaan etnografi komunikasi ini, peneliti diharuskan untuk menggali pola-pola komunikasi transendental yang dilakukan oleh suatu kelompok masyarakat sosial yang kemudian menjadi kebiasaan dan dilakukan secara terus-menerus sehingga menjadi sebuah simbol dan makna yang menjadi ciri khas masyarakat seperti kebiasaan beribadah sholat 5 waktu yang dilakukan oleh masyarakat beragama Islam. Adapun pemanfaatan media sosial whatsapp digunakan peneliti untuk melakukan wawancara online dengan informan dari Desa Cicukang RW 06 Kota Bandung.

P1 mengungkapkan bahwa pandemi Covid19 ini menyebabkan banyak aktivitas terhambat seperti sekolah, bekerja dan lain-lain. Selain itu, ia juga menjelaskan agar masyarakat tetap bersikap tenang dan menjaga kesehatan, memperbanyak ibadah di rumah, karena Allah baginya merupakan sumber ketenangan. Kegiatan lainnya yang dapat memberikan ketenangan hati dan terhindar dari stress yaitu membaca Al-Quran. Dengan demikian, dapat disimpulkan bahwa komunikasi transendental yang dilakukan oleh informan pertama berzikir, sholat dan membaca Al-Quran.

Menurut P2, pandemi Covid-19 saat ini menyebabkan banyak aktivitas terhambat seperti akses perjalanan dan kegiatan jual beli. Selain itu berita Covid-19 yang semakin memburuk harus dapat ditanggapi dengan bijak sehingga tidak menyebabkan ketakutan yang berlebihan. Ia juga berpendapat bahwa dengan menyibukkan diri dirumah dengan memperbanyak ibadah seperti tilawah Al-Qur'an karena Al-Qur'an dapat memberikan ketenangan sehingga terhindar dari stres. Ia menjelaskan cara menjalin komunikasi transendental yang ia lakukan dan menjadi kebiasaan sehari-hari seperti mengoptimalkan ibadah yaumiah dan selalu berusaha bersyukur atas nikmat apapun yang Allah SWT titipkan.

P3 berpendapat bahwa pandemi yang semakin memburuk merupakan tanggung jawab pemerintah dan masyarakat. Keduanya harus ikut andil dalam melaksanakan protokol kesehatan. Selain itu menurutnya kegiatan seperti bekerja dan berolahraga diluar rumah menjadi terhambat semenjak adanya pandemi. Saran yang ia berikan untuk mengisi kegiatan dirumah adalah masyarakat dapat memperbanyak beribadah seperti membaca Al-Quran, sholat dan berdoa. Karena Allah adalah sebaik-baiknya penolong. Beribadah juga menjadi hal positif sehingga terhindar dari stres. Menurutnya salah satu cara menjalin komunikasi transendental adalah seperti menjalankan ibadah wajib maupun sunnah dan sholat dengan khusyu'.

P4 berpendapat bahwa berita pandemi yang saat ini menimbulkan kecemasan dan ketakutan kepada masyarakat. Banyak kegiatan seperti silaturahim, bekerja dan bersosialisasi menjadi terhambat. Saran yang ia berikan adalah dengan mengkonsumsi makanan bergizi dan memperbanyak ibadah akan membuat tubuh sehat dan terhindar dari stres. Membaca Al-Quran juga membuat hati tenang sehingga tidak menimbulkan stres berlebihan pada diri. Menurutnya cara menjalin komunikasi transendental yang telah menjadi kebiasaan sehari-hari seperti sholat 5 waktu, berzikir, berdoa.

Saat mewawancarai P5, ia menjelaskan bahwa kondisi pandemi membuat banyak kerugian terutama pada ekonomi masyarakat. Ditambah lagi, sekolah juga harus berhenti walaupun ada daring namun tidak efektif. Ia juga mengungkapkan bahwa masyarakat harus selalu menjaga kesehatan diri dan lingkungan selama pandemi serta beribadah di rumah seperti membaca Al-Quran akan membuat hati tenang dan imun tubuh meningkat. Saat berkomunikasi dengan Allah SWT hati menjadi tenang dan pikiran akan lebih terbuka sehingga akan terhindar dari stres. Jadi, cara ia menjalin komunikasi transendental telah menjadi kebiasaan sehari-hari seperti sholat, mengaji, dzikir dan shodaqoh.

Menurut P6, selama pandemi Covid-19 masyarakat harus tetap tenang serta dapat memilah dan memilih informasi. Ia juga mengatakan kegiatan yang berhubungan dengan banyak orang menjadi terbatas. Baginya yang terpenting selalu menjaga kesehatan dengan makan, tidur dan 
olahraga seperti biasa dirumah. Salah satu hal penting adalah banyak berzikir dan beribadah sehingga hati lebih tenang dan diri menjadi sehat serta terhindar dari stres. Selain itu menurutnya cara menjalin komunikasi transendental yang menjadi kebiasaan sehari-hari dilakukan seperti beribadah, berdoa dan tadarus.

P7 berpendapat kondisi pandemi Covid-19 saat ini menimbulkan rasa takut terutama karena banyaknya korban meninggal dunia. Selain itu menurutnya pandemi menyebabkan kecemasan kepada masyarakat. Tapi yang terpenting tetap menjaga kesehatan dan tetap tenang dalam menghadapi situasi saat ini. Ia pun mengatakan beribadah merupakan hal penting yang memberikan dampak positif pada tubuh. Selain itu cara menjalin komunikasi transendental yang menjadi kebiasaan sehari-hari seperti beribadah sholat dan membaca Al-Quran.

Menurut P8, kondisi pandemi Covid-19 saat ini menyebabkan kekhawatiran dan kecemasan serta membuat aktivitas di luar rumah menjadi terbatas seperti berwisata. Disimpulkan bahwa selama pandemi yang terpenting menjaga kesehatan diri, perbanyak berdoa dan beribadah. Karena Allah adalah pemberi ketenangan. Jika hati tenang dan tubuh sehat maka akan terhindar dari stres. Sebagai salah satu contohnya yakni dengan komunikasi transendental yakni seperti berdoa, sholat dan berdzikir.

Menurut pengamatan $\mathrm{P}$, selama ini berita covid-19 yang semakin memburuk bisa saja hoax sehingga menyebabkan kecemasan di masyarakat. Sudah tentu pandemi ini membuat semua aktivitas terbatas dan terhambat. Menurutnya yang terpenting saat ini adalah menjaga kesehatan diri dan perbanyak ibadah selama di rumah, seperti tadarus Al-Qur'an yang bisa membuat hati menjadi tenang sehingga terhindar dari stres. Baginya kegiatan komunikasi transendental yang menjadi kebiasaan sehari-hari, seperti sholat, tadarus dan berdzikir.

P10 menjelaskan bahwa pandemi Covid-19 merupakan bencana dunia yang perlu penanganan khusus karena pandemi ini membuat semua aktivitas terhambat. Baginya menjaga kesehatan adalah hal terpenting selama pandemi serta selalu berfikir positif. Selalu berkomunikasi dan mendekatkan diri pada Allah SWT akan membuat hati lebih tenang sehingga terhindar dari stres. Ia mengatakan beribadah sudah menjadi kebiasan umat islam. Ia juga mengatakan komunikasi transendental yang ia lakukan yaitu melaksanakan perintah Allah SWT dan menjauhi laranganNya.

P11 berpendapat bahwa berita pandemi yang semakin memburuk terlalu dilebih-lebihkan sehingga menimbulkan kepanikan yang membuat imunitas tubuh menurun. Aktifitas sehari hari seperti bekerja, sosialisasi dan silaturahmi juga menjadi terganggu. Oleh karena itu, menjaga kesehatan diri sangatlah penting karena dapat berpengaruh terhadap kesehatan keluarga. Yang terpenting tetap tenang, berolahraga dan beribadah seperti tadarus Al-Quran. Ia pun mengatakan untuk selalu berkomunikasi dengan Allah SWT karena hanya Allah lah sebaik-baiknya penolong. Hal ini dapat dilakukan dengan cara komunikasi transendental seperti memperbanyak berdoa, bertakbir, tahlil dan tahmid serta memperbanyak mendekatkan diri kepada Allah melalui sholat, dzikir dan berdoa.

Menurut pendapat P12, dengan adanya berita pandemi Covid-19 yang semakin memburuk ini diharapkan masyarakat lebih patuh terhadap protokol kesehatan. Ia mengatakan pandemi ini membuat aktifitas sehari hari menjadi terganggu seperti wirausaha. Oleh karena itu ia menganjurkan untuk tetap menjaga kesehatan dan menjalani semua aktifitas dengan tenang serta berolahraga didalam rumah. Selain itu beribadah memberikan dampak baik bagi kesehatan yaitu salah satunya dengan membaca Al-Qur'an agar hati menjadi tenang dan mendapat ridho Allah dan menurutnya yang terpenting adalah menjaga imunitas tubuh agar terhindar dari stres. Semua itu bisa dilakukan dengan komunikasi transendental yang menjadi kebiasaan sehari-hari seperti mejalankan ibadah yang diperintahkan Allah SWT.

P13 mengatakan bahwa pandemi Covid-19 menimbulkan rasa takut untuk beraktifitas di luar rumah, begitu juga terganggunya kegiatan sekolah. Menurutnya yang terpenting adalah harus selalu tetap tenang, menjaga kesehatan dan berolahraga di dalam rumah. Selain itu, memperbanyak berkomunikasi dengan Allah SWT dengan beribadah seperti berdoa dan tadarus Al-Quran agar hati menjadi tenang dan terhindar dari stres. Ini berarti cara menjalin komunikasi transendental yang ia lakukan ialah melaksanakan sholat dan memperbanyak berdoa serta tadarus Al-Quran.

P14 mengungkapkan bahwa berita pandemi Covid-19 menimbulkan rasa khawatir dan panik yang berlebih, namun penting untuk tetap waspada dan mengurangi kepanikan. Aktifitas sehari hari yang mengharuskan keluar rumah menjadi terganggu. Ia juga mengatakan pentingnya menjaga kesehatan dan menerapkan protokol kesehatan serta untuk tidak terlalu berfikiran negatif karena akan membuat stres dan mempengaruhi imunitas tubuh. Solusi yang ia berikan adalah dengan menjalankan olahraga, makan makanan bergizi, membahagiakan diri dengan hobi dan tetap beribadah terhadap Allah SWT dapat meningkatkan imunitas tubuh karena membuat hati lebih tenang dan terhindar dari stres. Dalam menjalin komunikasi transendental, ia melaksanakan sholat wajib dan sunnah, berdzikir, berdoa dan mengaji.

P15 menjelaskan bahwa berita pandemi Covid-19 yang kian memburuk terlalu dibesarbesarkan sehingga membuat masyarakat ketakutan 
dan gaduh. Aktifitas sehari-hari seperti perjalanan keluar kota menjadi terganggu karena adanya penyekatan tiap wilayah. Menurutnya menjaga kesehatan sangat penting, berpikir cermat dan percaya terhadap Sang Pencipta serta menjalin hubungan komunikasi dengan Allah SWT dapat menenangkan diri dan menghindari stres. Cara menjalin komunikasi transcendental yang ia lakukan adalah membaca dan mengerti makna AlQuran walau hanya sedikit dan menjalan perintah Allah SWT serta menjauhi larangan-Nya.

Tabel 1

Daftar Informan

\begin{tabular}{|c|c|c|c|c|c|c|}
\hline No & Kode & Nama & Usia & Gender & Domisili & Pekerjaan \\
\hline 1 & $\mathrm{P} 1$ & Faris Tya R & 22 tahun & Laki-laki & RT 01 & Tidak bekerja \\
\hline 2 & $\mathrm{P} 2$ & Aris Al-Qorni & 23 tahun & Laki-laki & RT 02 & Guru SD \\
\hline 3 & P3 & Trio $\mathrm{N}$ & 23 tahun & Laki-laki & RT 01 & Tidak bekerja \\
\hline 4 & $\mathrm{P} 4$ & Yuliani & 23 tahun & Perempuan & RT 01 & Mahasiswa \\
\hline 5 & P5 & Shela Oktaviani P & 18 tahun & Perempuan & RT 01 & Tidak bekerja \\
\hline 6 & P6 & Syakira Noorbani Y & 18 tahun & Perempuan & RT 01 & Mahasiswa \\
\hline 7 & P7 & Vicky & 20 tahun & Perempuan & RT 03 & SPG \\
\hline 8 & P8 & Bahira Salsabila & 24 tahun & Perempuan & RT 04 & $\begin{array}{c}\text { Karyawan } \\
\text { pabrik }\end{array}$ \\
\hline 9 & P9 & Tomy Lee & 25 tahun & Laki-laki & RT 01 & $\begin{array}{c}\text { Karyawan } \\
\text { pabrik }\end{array}$ \\
\hline 10 & $\mathrm{P} 10$ & Erni Herawati & 25 tahun & Perempuan & RT 01 & Guru TK \\
\hline 11 & $\mathrm{P} 11$ & Syahrial Afandi & 24 tahun & Laki-laki & RT 01 & $\begin{array}{c}\text { Karyawan } \\
\text { pabrik }\end{array}$ \\
\hline 12 & $\mathrm{P} 12$ & Hadian Nurrojman & 25 tahun & Laki-laki & RT 02 & Wirausaha \\
\hline 13 & $\mathrm{P} 13$ & Sabila Nurazizah & 17 tahun & Laki-laki & RT 03 & Tidak bekerja \\
\hline 14 & $\mathrm{P} 14$ & Mega Mutia Maeskina & 22 tahun & Perempuan & RT 04 & Content creator \\
\hline 15 & $\mathrm{P} 15$ & Cindy Sovhie & 22 tahun & Perempuan & RT 04 & Mahasiswa \\
\hline
\end{tabular}

Sumber: diolah dari data lapangan, 2021 
Tabel 2

Hasil Wawancara

\begin{tabular}{|c|c|c|}
\hline No & $\begin{array}{c}\text { Kode } \\
\text { Informan }\end{array}$ & Uraian Penelitian \\
\hline 1 & $\mathrm{P} 1$ & $\begin{array}{l}\text { Mengerjakan sholat baik yang wajib maupun yang sunah, memperbanyak dzikir } \\
\text { dan membaca Al-Quran serta bersikap tenang yakin bahwa Allah adalah sumber } \\
\text { ketenangan. }\end{array}$ \\
\hline 2 & $\mathrm{P} 2$ & $\begin{array}{l}\text { Memperbanyak ibadah seperti memperbanyak tilawah Al-Quran dan selalu } \\
\text { bersyukur kepada Allah. }\end{array}$ \\
\hline 3 & P3 & $\begin{array}{l}\text { Mengerjakan sholat lebih khusyu baik yang wajib maupun yang sunah, } \\
\text { memperbanyak membaca Al-Quran dan berdoa. }\end{array}$ \\
\hline 4 & P4 & $\begin{array}{l}\text { Mengerjakan sholat } 5 \text { waktu, berdzikir dan berdoa serta membaca Al-Quran karena } \\
\text { memberikan ketenangan. }\end{array}$ \\
\hline 5 & P5 & Mengerjakan sholat, dzikir, mengaji dan bersedekah. \\
\hline 6 & P6 & $\begin{array}{l}\text { Memperbanyak ibadah, berdoa dan tadarus serta berdzikir karena membuat hati } \\
\text { lebih tenang dan terhindar dari stress. }\end{array}$ \\
\hline 7 & P7 & $\begin{array}{l}\text { Mengerjakan sholat dan membaca Al-Quran karena memberikan dampak positif } \\
\text { bagi tubuh. }\end{array}$ \\
\hline 8 & P8 & $\begin{array}{l}\text { Memperbanyak berdoa dan beribadah kepada Allah karena Allah pemberi } \\
\text { ketenangan. }\end{array}$ \\
\hline 9 & P9 & $\begin{array}{l}\text { Mengerjakan sholat, memperbanyak dzikir dan tadarus Al-Quran karena ini } \\
\text { membuat hati lebih tenang dan tidak stress. }\end{array}$ \\
\hline 10 & P10 & $\begin{array}{l}\text { Beribadah sudah menjadi kebiasaan umat Islam, hal yang terpenting adalah } \\
\text { melaksanakan perintah Allah SWT dan menjauhi larangan-Nya. }\end{array}$ \\
\hline 11 & P11 & $\begin{array}{l}\text { Memperbanyak doa, bertakbir, tahlil dan tahmid karena Allah adalah sebaik-baik } \\
\text { penolong serta mendekatkan diri kepada Allah melalui ibadah sholat, dzikir dan } \\
\text { membaca Al-Quran. }\end{array}$ \\
\hline 12 & $\mathrm{P} 12$ & $\begin{array}{l}\text { Menjalankan ibadah sesuai perintah Allah, utamanya memperbanyak membaca Al- } \\
\text { Quran agar mendapatkan ridho Allah dan menenangkan hati. }\end{array}$ \\
\hline 13 & P13 & Menjalankan sholat wajib 5 waktu dan banyak berdoa serta membaca Al-Quran. \\
\hline 14 & P14 & Tetap beribadah melaksanakan sholat wajib dan sunah, berdzikir, berdoa, mengaji. \\
\hline 15 & P15 & $\begin{array}{l}\text { Menjalankan perintah Allah SWT dan menjauhi larangan-Nya serta membaca dan } \\
\text { memahami Al-Quran walaupun hanya sedikit. }\end{array}$ \\
\hline
\end{tabular}




\section{Pembahasan Penelitian}

Komunikasi merupakan proses penyampaian pesan dari komunikator kepada komunikan melalui suatu media yang menciptakan efek (Wahidah : 2015). Dari definisi sederhana ini muncul pertanyaan bagaimana berkomunikasi dengan Allah yang secara kasat mata tidak dapat dilihat namun hanya dapat diyakini dan dirasakan keberadaannya. Bagaimana memperkenalkan wujud komunikator atau komunikan dalam proses komunikasi ini, media apa yang digunakan, dan bagaimana memandang dampak yang dihasilkan dalam proses komunikasi tersebut. Hal inilah yang ingin dijelaskan dalam komunikasi transendental. Realisasi kepercayaan manusia terwujud dalam penghambaan kepada Tuhan yang disembah melalui komunikasi trasendental. Salah satu tipe komunikasi yang tidak banyak dibahas karena bersifat abstrak, tidak mudah untuk diukur dan diamati secara empirik. Namun, sesungguhnya justru komunikasi tipe inilah yang paling esensial dalam kehidupan di dunia karena sangat mempengaruhi untuk kehidupan di akhirat nanti.

Sebagai seorang muslim tentu penting menjalin hubungan dengan Sang Pencipta karena segala hal telah diatur oleh Allah SWT. Allah juga telah memerintahkan manusia sebagai hambanya untuk beribadah sebagai salah satu tujuan penciptaannya

Seperti dalam QS. Az-zariyat : 56

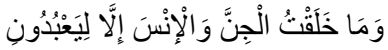

Tidaklah Aku menciptakan jin dan manusia kecuali untuk beribadah kepada-Ku.

Beribadah telah menjadi suatu kebiasaan yang telah melekat pada setiap muslim. Setiap kegiatan apapun yang dilakukan untuk mencari ridho Allah maka akan bernilai ibadah. Ciri seorang muslim dilihat dari ibadahnya seperti sholat 5 waktu, puasa ramadhan, berdoa, berdzikir dan membaca Al-Qur'an. Menjalin komunikasi dengan Allah memberikan manfaat pada tubuh seperti :

1. Mengajarkan hidup sehat

Dalam islam berpuasa selain menahan haus dan lapar puasa juga merupakan salah satu cara menjaga diri agar tetap sehat. Saat berpuasa organ tubuh akan mendetoks racun yang ada di dalamnya. Selain itu islam juga melarang untuk mengkonsumsi alkohol, darah dan makanan haram lainnya.

\section{Membuat hidup menjadi lebih positif}

Dalam penelitian ditemukan bahwa orang yang memiliki keyakinan terhadap suatu agama dan menjalaninya dengan baik cenderung berpola pikir positif atau optimis, punya lebih banyak teman, dan lebih dekat dengan keluarga.

Semua hal ini adalah faktor-faktor yang mendukung kesehatan. Optimisme akan membuat tubuh lebih sehat karena dapat memperkuat sistem kekebalan tubuh, yang dalam jangka panjang juga mampu memperpanjang usia harapan hidup.
Lebih lanjut dikatakan bahwa orang yang meyakini agama dan menjalaninya dengan sungguh-sungguh memiliki risiko lebih rendah untuk mengalami masalah kejiwaan, seperti depresi dan gangguan kecemasan.

\section{Mengurangi stres}

Ritual agama, seperti berdoa dan shalat, juga dapat menjadi cara untuk menjaga diri dari stres. Mengendalikan stres dengan baik dapat membantu tubuh terhindar dari berbagai penyakit, seperti tekanan darah tinggi dan penyakit jantung.

Di samping itu, saat menghadapi tekanan hidup atau terserang penyakit berat, peneliti menemukan bahwa orang yang beragama cenderung lebih kuat secara mental dan lebih mampu bertahan dalam melawan masalah dan penyakitnya.

\section{Memberikan tujuan hidup}

Agama juga akan membuat orang memiliki tujuan hidup. Inilah alasan mengapa pada sebuah penelitian ditemukan bahwa orang beragama lebih merasa bahagia dan puas akan kehidupannya.

Menjalin komunikasi transendental membuat hati menjadi tenang seperti dalam QS. Ar-Rad : 28 Allah Subhanahu Wa Ta'ala berfirman:

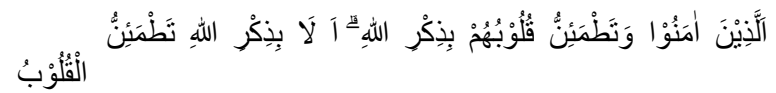

alladziina aamanuu wa tathma-innu quluubuhum bidzikrillaah, alaa bidzikrillaahi tathmainnul-quluub

"(yaitu) orang-orang yang beriman dan hati mereka menjadi tenteram dengan mengingat Allah. Ingatlah, hanya dengan mengingat Allah hati menjadi tenteram."

(QS. Ar-Ra'd 13: Ayat 28)

\section{Pembahasan hasil wawancara dan observasi}

Setelah melakukan wawancara terhadap 15 informan yang dipilih peneliti sesuai dengan kriteria dalam penelitian dan dilakukannya observasi, maka peneliti menarik maka dapat disimpulkan bahwa semenjak pandemi Covid-19 di tahun 2020 hingga saat ini yang situasinya semakin memburuk membuat sebagian masyarakat merasa cemas, khawatir bahkan hingga terjadinya panic buying namun tidak sedikit pula masyarkat yang bersikap biasa saja dalam menanggapi situasi saat ini namun tetap menaati protokol kesehatan.

Banyak aktivitas sehari-hari yang menjadi terganggu seperti bekerja, sekolah, berolahraga diluar rumah, bersosialisasi bahkan bersilaturahim pun menjadi terbatas semenjak adanya pandemi. Selain itu, semua informan setuju bahwa menjaga kesehatan jasmani dan rohani adalah hal utama yang harus diperhatikan saat ini. Salah satu caranya dengan makan makanan bergizi, berolahraga ringan di rumah dan memperbanyak ibadah. 
Para informan mengungkapkan kesetujuannya terhadap pendapat peneliti bahwa beribadah memberikan dampak positif dan memberikan ketenangan pada diri seseorang. Hal ini juga diperkuat dengan pernyataan informan bahwa selama mereka beribadah, hati mereka menjadi lebih tenang, fikiran lebih positif dan terhindar dari stres. Informan juga rutin melaksanakan ibadah seperti sholat 5 waktu, berdoa, berdzikir dan membaca Al-Qur'an bukan hanya sebagai cara menjaga kesehatan, namun juga sebagai suatu kewajiban yang telah menjadi kebiasaan umat Islam.

Seluruh informan yang diwawancarai menyatakan pula bahwa karena mereka memiliki banyak waktu di rumah maka ada peningkatan intensitas ibadah mereka dibandingkan ketika sebelum pandemi Covid19 terjadi. Bahkan ada yang belajar menghafalkan AlQuran seperti yang dilakukan oleh P1. Rata-rata mereka memperbanyak intensitas membaca Al-Quran dan menambah pelaksanaan sholat sunnah seperti sholat tahajud dan sholat dhuha selain sholat rawatib. Walaupun demikian, informan P9 menyatakan hal yang berbeda. Ia menyatakan bahwa kegiatan ibadah yang ia lakukan merupakan ibadah seperti biasanya yang ia lakukan ketika sebelum pandemi Covid-19 terjadi. Ia juga memaparkan bahwa peningkatan ibadah sebaiknya hanya karena Allah bukan karena adanya pandemic Covid-19.

Dalam wawancara dan observasi para informan juga mengungkapkan bahwa stres memberikan pengaruh besar terhadap tubuh. Jika seseorang stres maka imun tubuhnya akan menurun dan menyebabkan lemah sehingga mudah terpapar virus. Itu sebabnya penting bagi masyarakat untuk tetap tenang menghadapi situasi pandemi saat ini. Tetap memilah informasi yang benar dan memberikan tanggapan dengan bijak. Beraktivitas seperti biasa dengan tetap menerapkan protokol kesehatan. Menjaga kesehatan diri adalah keharusan setiap orang, karena hanya diri sendiri yang mengetahui kondisi tubuh apakah dalam keadaan baik atau tidak. Selain itu dengan memperbanyak ibadah, berdoa dan berzikir dapat mengurangi ketakutan dan kecemasan pada diri seseorang. Hal ini tentu membuat tubuh lebih mudah mengendalikan stres. Dengan adanya proses komunikasi transendental, pikiran akan lebih teralihkan dan tidak terus-menerus merespon rasa takut karena adanya Covid-19. Stres berlebihan akan berdampak buruk pada tubuh dan membuat imun tubuh lemah sehingga mudah terpapar penyakit. Dengan memperbanyak kegiatan transenden (berdoa, beribadah, berzikir) hati dan pikiran akan lebih tenang sehingga tubuh akan jauh lebih bugar.

\section{PENUTUP}

\section{Kesimpulan}

Pada bab ini peneliti akan mejabarkan kesimpulan dari hasil penelitian yang di dapatkan peneliti di Desa Cicukang RW 06 Kota Bandung :
1. Setelah melakukan wawancara terhadap 15 informan yang dipilih peneliti sesuai dengan kriteria dalam penelitian dan dilakukannya observasi, maka peneliti menarik kesimpulan sebagai berikut : Semenjak pandemi covid-19 di tahun 2020 hingga saat ini yang situasinya semakin memburuk membuat sebagian masyarakat merasa cemas, khawatir bahkan hingga terjadinya punic buying namun tidak sedikit pula masyarkat yang bersikap biasa saja dalam menanggapi situasi saat ini namun tetap menaati protokol kesehatan. Menjalin komunikasi transendental merupakan hal yang sangat penting terutama bagi masyarakat beragama, baik saat keadaan pandemi maupun tidak. Apalagi komunikasi transendental seperti beribadah, berdoa, dzikir dan tadarus al-qur'an telah menjadi suatu kebiasaan dan norma serta agama yang melekat dalam masyarakat. Hal ini juga diperkuat dengan pernyataan informan bahwa selama mereka beribadah, hati mereka menjadi lebih tenang, fikiran lebih positif dan terhindar dari stres. Selain itu dengan memperbanyak ibadah, berdoa dan berzikir dapat menguragi ketakutan dan kecemasan pada diri seseorang hal ini tentu membuat tubuh lebih mudah mengendalikan stres.

2. Komunikasi transendental adalah komunikasi yang bersifat abstrak, yang artinya tidak dapat dilihat namun bisa dirasakan. Selain itu, komunikasi ini juga memiliki pengaruh penting terhadap diri seseorang. Menurut pendapat para ahli seseorang yang menjalin hubungan baik dengan Tuhannya dan meyakini sepenuhnya agamanya melalui media seperti berdoa dan beribadah memiliki risiko lebih rendah untuk mengalami masalah kejiwaan, seperti depresi dan gangguan kecemasan. Di samping itu, saat menghadapi tekanan hidup atau terserang penyakit berat, peneliti menemukan bahwa orang yang beragama dengan keimanan yang kuat cenderung lebih kuat secara mental dan lebih mampu bertahan dalam menghadapi masalah dan penyakitnya.memiliki kebaruan yang baik adalah referensi yang diterbitkan selama 10 tahun terakhir. Setiap artikel paling tidak berisi 10 (sepuluh) daftar pustaka acuan.

\section{Saran}

Berdasarkan hasil pembahasan penelitian diatas, maka peneliti memberikan saran sebagai berikut :

1. Dalam menghadapi pandemi covid-19 saat ini, masyarakat dan pemerintah memiliki tanggung jawab bersama. Keduanya harus bekerja sama untuk mengatasi situasi saat ini. Ketika pemerintah fokus terhadap perbaikan ekonomi dan menghentikan penularan covid-19 maka tugas masyarakat adalah membantu pemerintah dengan mentaati himbauan yang diberikan 
seperti taat protokol $3 \mathrm{M}$, beraktivitas di dalam rumah dan yang terpenting tetap menjaga kesehatan.

2. Masyarakat harus memperbanyak beraktivitas positif di dalam rumah, salah satunya dengan memperkuat hubungan dengan Tuhannya (komunikasi transendental) karena Allah SWT adalah sebaik-baiknya penyembuh dan pemberi ketenangan hati. Hal ini akan lebih mudah dilaksanakan karena beribadah sudah menjadi kewajiban dan kebiasaan sehari-hari masyarakat muslim seperti sholat 5 waktu, berdzikir, berdoa dan tadarus Al-Quran. Sudah banyak penelitian yang membuktikan bahwa beribadah memberikan dampak positif pada kesehatan tubuh serta terhindar dari stres.

\section{REFERENSI}

Ansar Suherman. (2020). Buku Ajar Teori-teori Komunikasi.

Boham, S. E. (2013). Models of parental communication towards the behavior of autism children. II(4

Buana, D. R. (2020). Analisis Perilaku Masyarakat Indonesia dalam Menghadapi Pandemi Virus Corona (Covid-19) dan Kiat Menjaga Kesejahteraan Jiwa.

Gunawan, H. (2013). JENIS POLA KOMUNIKASI ORANG TUA DENGAN. 1(3), 218-233.

Issn, F. (2015). Komunikasi Transendental Manusia Tuhan Oleh: Wahidah Suryani IAIN Sultan Amai Gorontalo. 12, 150-163.

M, M. M., \& Hanifah, U. (2020). Menjaga Kesehatan Mental di Tengah Pandemi Covid-19 melalui Takziyatun Nafs.

Mokodompit, F. R. (2020). PENGARUH KOMUNIKASI ORGANISASI TERHADAP EFEKTIVITAS KINERJA PADA PT.RADIO MEMORA ANOA INDAH OLEH:

Muslim, M. . (2020). Manajemen Stress pada Masa Pandemi Covid-19" 193. 23(2), 192-201.

Nasution, D. H. H. A. (2020). PATOLOGI SOSIAL DAN PENDIDIKAN ISLAM KELUARGA.

Nurhadi, Z. F., Kurniawan, A. W., Studi, P., Komunikasi, I., \& Garut, U. (2017). EFEKTIVITAS PESAN
KOMUNIKASI. (1), 90-95.

Parwanto, E. (2020). Virus Corona (2019-nCoV) penyebab COVID-19. 3(1), 707-708. https://doi.org/10.1038/nsmb1123

Setiawan, L. (2019). Terdapat Pengaruh Hubungan Kerja dan Komunikasi terhadap Kinerja Karyawan. 10-40.

Supratman, L. P., \& Adi Bayu Mahadian. (2018). PSIKOLOGI KOMUNIKASI.

Suryani, I., \& Amri, A. (2019). Pengaruh Menghafal Al-Qur'an Sebagai Komunikasi

\begin{abstract}
Transendental Terhadap Kecerdasan Emosional (Studi Pda Santri Madrasah Ulumul Al- Qur'an, Aceh Besar). 4(3).
\end{abstract}

Taufik, M. T. (2013). Memperkenalkan Komunikasi Transdenta.

Thadi, R. (2017). Komunikasi transendental: shalat sebagai bentuk komunikasi transendent. 45-52.

Tua, N., \& Gaol, L. (2016). Teori Stres: Stimulus , Respons , dan Transaksional. 24(1), 1-11. https://doi.org/10.22146/bpsi.11224 